\title{
BIOEDUSCIENCE
}

ISSN: 2614-1558

http://journal.uhamka.ac.id/index.php/bioeduscience

\section{Implementation and Factors that Affect Online Learning in Biology Lessons}

\author{
Wulandari $^{1 *}$, Sri Wardhani1 ${ }^{1}$, Indawan ${ }^{1}$ \\ ${ }_{1}^{1}$ Pascasarjana Pendidikan Biologi, Universitas Muhammadiyah Palembang, Jl.Jendral Ahmad Yani, Palembang, Indonesia 513078
}

*Correspondent Email: ulanda939@gmail.com

Check for updates

\section{ARTICLE INFO}

Article history

Received: 17 Feb 2021

Accepted: 12 Jun 2021

Published: 31 Aug 2021

\section{Keywords:}

Biology learning;

Implementation;

Online learning;

Distance learning;

\section{A B S T R A C T}

Background: Online learning changes the learning pattern usually done face-to-face into a distance education system to influence it. This also has an impact on biology lessons at Xaverius High School Lubuklinggau. This study aims to determine the perception of the implementation of online learning in biology lessons and determine the factors that influence it. Methods: This research uses descriptive qualitative with data collection techniques using observation, interviews, questionnaires, and documentation which are then analyzed by technical analysis of Miles \& Huberman. The research subjects were biology teachers and all grades X, XI, and XII science students at Xaverius High School Lubuklinggau. Results: the implementation of learning in biology lessons that have been carried out at Xaverius Lubuklinggau High School there are planning, implementation and evaluation activities as well as face-to-face learning, but in the implementation, there are factors that influence, namely the material cannot be explained, the response of class $\mathrm{X}$ students is less active, supervision of the assessment, the ability of teachers to use various educational applications, difficulty in assessing the character of students, some students do not understand the material provided, and the learning environment. Conclusion: The implementation of online learning that is applied there are still planning, implementation and evaluation activities, but in the implementation, several factors influence both supporting and inhibiting factors.

\section{Implementasi dan Faktor-faktor yang Mempengaruhi Pembelajaran Daring pada Pelajaran} Biologi

\section{A B S T R A K}

Latar Belakang: Pembelajaran daring mengubah pola belajar yang biasa dilakukan dengan tatap muka menjadi sistem pendidikan jarak jauh, sehingga akan terdapat faktor yang mempengaruhinya. Hal ini juga berdampak pada pelajaran biologi di SMA Xaverius Lubuklinggau. Penelitian ini bertujuan untuk mengetahui persepsi implementasi pembelajaran daring pada pelajaran biologi dan mengetahui faktor-faktor yang mempengaruhinya. Metode: penelitian ini menggunakan deskriptif kualitatif dengan teknik pengumpulan data dengan menggunakan observasi, wawancara, kuesioner, dan dokumentasi yang kemudian dianalisis dengan teknis analisis Miles \& Huberman. Subjek penelitian yaitu guru biologi dan semua siswa kelas X, XI, dan XII IPA di SMA Xaverius Lubuklinggau. Hasil: implementasi pembelajaran pada pelajaran biologi yang telah dilakukan di SMA Xaverius Lubuklinggau terdapat kegiatan perencanaan, pelaksanaan dan evaluasi sama halnya seperti pembelajaran tatap muka, tetapi dalam pelaksanaan terdapat faktor-faktor yang mempengaruhi yaitu materi tidak dapat dijelaskan, respon siswa kelas $\mathrm{X}$ kurang aktif, pengawasan penilaian, kemampuan guru dalam menggunakan berbagai aplikasi pendidikan, sulit dalam menilai karakter siswa, beberapa siswa tidak memahami materi yang diberikan, dan lingkungan saat belajar. Kesimpulan: Implementasi pembelajaran daring yang diterapkan masih terdapat kegiatan perecanaan, pelaksanaan dan evaluasi, tetapi dalam penerapan terdapat beberapa faktor yang mempengaruhi baik faktor yang mendukung maupun faktor yang menghambat.

(C) 2021 by authors. License BIOEDUSCIENCE. UHAMKA, Jakarta. This article is open access distributed under the terms and conditions of a Creative Commons Attribution (CC-BY) license.

\section{Introduction}

The spread of the Covid-19 virus in early 2020 led Indonesia to issue Circular Letter number 4 of 2020 concerning the Implementation of Education Policy in the Emergency Period of Corona Virus Disease (COVID-19), a policy to conduct online learning activities from home. This will turn learning activities usually done face-to-face into digital media learning activities (Fitriyani, Fauzi, \& Sari, 2020). Online learning is also considered able to accelerate the educational demands of the industrial revolution era 
4.0 because the learning system utilizes information technology.

Online learning is an innovation in learning that takes advantage of the development of information technology. According to Mustofa, Chodzirin, \& Sayekti (2019), online learning is a distance learning activity that uses various teaching methods and activities carried out separately from those who study. The problem is that online learning is a new thing in high school level learning because learning is usually done directly face-to-face between teachers and students in the classroom. Therefore, online learning will be a new challenge and requires schools, teachers, and students to adapt to new activities or ways of learning. This transition of online learning also occurs suddenly without any preparation in advance, so factors or obstacles will affect the implementation of online learning (Regianti, 2020). Therefore, online learning forces schools to be more creative and innovative in issuing policies in addressing problems and developing learning activities, so that curriculum objectives can be achieved as expected (Mutaqinah \& Hidayatullah, 2020).

The problem is that not all teachers and students master the developing technology (Agoestyowati, 2020). Based on the results of Artikawati research (2016), online learning causes a lack of communication between teachers and students during learning and the lack of learning models used during online learning that affect student achievement. Online learning also requires students to adjust to new ways of learning, demands to learn independently at home, and the lack of supervision during learning so that it cannot be denied there will be some problems that students will face during learning (Agoestyowati, 2020). Therefore, a teacher plays a very important role in online learning, because the teacher will arrange the scenario of learning activities that will be carried out to achieve learning goals.

Teachers must innovate in creating a good learning process during online learning activities. The learning process is important in learning activities, whether or not an online learning goal depends on the learning process carried out. If the learning process goes well then the learning results will be achieved following expectations. Teachers can use applications that support in education such as Google Classroom, Zoom and WhatsApp that can support the implementation of online learning (Dhull \& Sanksi, 2017). The implementation of online learning must still pay attention to the competencies to be taught. Online learning is not a learning activity that only provides materials or assignments to students through applications but online learning must also be thoroughly designed and implemented, and evaluations such as learning that is usually done in the classroom (Syarifudin, 2020).

The implementation of online learning is also influenced by several supporting factors that inhibit online learning effectiveness. These factors are divided into two, internal and external factors. Internal factors are factors that originate in students and teachers. External factors are factors that come from outside the student and teacher (Sukmawati, 2016). Therefore, it is crucial to analyze the implementation of online learning that has been applied so that it can know about the implementation of online learning that has been applied and know the factors that affect it, which then the results of this study can be a reference for improvement in implementing the following online learning activities. Online learning is also carried out in Lubuklinggau City. In this study, researchers chose Xaverius Lubuklinggau High School because Xaverius Lubuklinggau High School received the highest national examination score (UN) biology in Lubuklinggau City with a score of 65.38. This High School has also been accredited A and, when the research was conducted, has carried out online learning for approximately five months.

This study aims to find out how the implementation of online learning in biology lessons has been applied and know the factors that affect online learning, so it is expected that the results of this study can be helpful to provide information and can be considered in carrying out better online learning.

\section{Method}

\section{Scope of Research}

The method in this research uses qualitative descriptive methods with case study research strategies because each aspect must be outlined in detail and systematically (Syahmina, Tanjung, \& Rohani, 2020). The study was conducted in October 2020 at Xaverius Lubuklinggau High School. The subjects of the study are biology teachers and students of grades X, XI, XII IPA.

\section{Respondents}

Respondents in this study were one biology teacher, 35 students of class X IPA, 48 students of class XI IPA, and 33 students of class XII IPA.

\section{Research Instruments}

The research instruments used are observation sheets to find out the implementation of online learning on biology lessons and factors that affect online learning, interview sheets used to find out the implementation of online learning and the factors that affect it and questionnaire sheets used to find out the factors that affect online learning.

\section{Research Procedure}

The research procedures used in this research are divided into three stages: preparation, implementation, and completion. In the preparation phase, researchers look for information about the implementation of online learning, 
then create observation sheets about the implementation of online learning and the factors that affect it, interview sheets for teachers and students about the implementation of online learning, and questionnaire sheets about the factors affecting online learning. In the implementation stage, researchers conduct observations in classes $\mathrm{X}, \mathrm{XI}$ and XII IPA. Then conduct interviews with biology teachers and students, and distribute questionnaires to students of grades X, XI, and XII IPA using Google Form and take documentation. The documentation taken is a syllabus, RPP, assessment instrument, and photo during the research. The data was analyzed using Miles \& Huberman's analysis. In the completion stage, the researcher makes conclusions from the analysis that has been done.

\section{Data Collection and Data Analysis}

Data collection techniques are by observing online learning and the factors that affect it conducted in class $\mathrm{X}$, XI and XII IPA, interviews with biology teachers to find out the application of online learning and the factors that affect it, interviews with students to find out the application of online learning that has been done, questionnaires given to students of grades X, XI, XII IPA to find out the factors that affect learning. Online and documentation. The data obtained will be analyzed using Miles \& Huberman analysis consisting of 3 stages, namely data reduction (collecting, compiling, classifying the data obtained), display data (understanding, analyzing the data obtained) and verification (drawing conclusions from the data that has been analyzed).

\section{Result}

The implementation of online learning that is applied consists of planning, implementing and evaluating learning activities.

\section{Learning Planning}

Based on the results of interviews that have been conducted with Mrs. Niken Indra Koestina, S.Si as biology teacher of class X, XI and XII IPA are as follows.

a. Is the syllabus used during online learning a revision syllabus?

"Yes, the revised syllabus. The syllabus used has a character assessment".

b. During online learning activities, do you still make learning devices?

"Yes, you still have to make RPP, because it must be used as an archive and facilitate in carrying out learning activities.

c. Do you make rpp one sheet or what?

"Yes, we have used RPP one sheet".

Based on the interview, the learning tools that teachers have made before carrying out online learning activities are one sheet implementation plan (RPP) and syllabus.
It is also following the results of documentation and observation that the RPP used by teachers is RPP one sheet consisting of core components, namely learning objectives, learning activities and learning assessments. In contrast, complementary components consist of school identity, subject identity, class/semester, basic competence and time allocation. Based on the results of syllabus observations also used, namely, the syllabus that contains character assessment.

\section{Implementation of Learning in Class $X$}

The implementation of learning is any effort made intentionally by the teacher that can cause students to carry out learning activities. There are three activities in the implementation of learning, namely preliminary activities, core activities, and closing activities. Applications used during online learning are Google classroom, Youtube, Google Form, and Whatsapp to facilitate communication between teachers and students.

Based on the results of the study in class $\mathrm{X}$ biology lessons, in the preliminary activities, learning activities begin with the teacher saying a greeting "good morning", then the teacher conveys a perception such as asking about the student's news, or connecting the previous subject matter with the subject matter to be learned. The teacher also always explains the learning goals that will be achieved in this activity. At core activities, teachers provide material in the form of videos and PPT. The video and PPT have given questions that will be used as assignments for students. Teachers also allow students to ask questions about material that is not yet understood, but the student's response is less active. At the closing activities, the teacher asks students to conclude the material and close the learning by encouraging students such as expressing "happy learning", "keep the spirit". In online learning activities, there are also practicum activities.

Based on the results of interviews conducted with class $\mathrm{X}$ students, it is as follows.

1) How are the online learning activities that have been implemented?

"The teacher explains the learning steps, then provides videos and assignments".

"Practicum activities, recording video material and so on".

2) How are the practicum activities that you have done during online learning activities?

"Practicum activities are done by writing answers on answer sheets and sending photos as proof we hold a practicum at home".

"The practical task is that the teacher asks for a video or photo in performing the practical task that has been done".

3) Describe practical applications applied to online learning activities? 
"Google Classroom, and Youtube that makes it easy to understand the material".

"Google Classroom is an app that helps us learn online".

4) Explain the effective learning media applied to online learning activities?

"Learning with video keeps me from getting bored".

"Explanations with videos are easier to understand".

Based on the interview, online learning activities on biology lessons conducted are teachers delivering learning instructions, providing material in the form of learning videos, assignments, discussions and independent practicums. The most effective applications used are google classroom and Youtube because it helps students in learning. At the same time, the effective medium in learning is video because it makes it easy to understand the material and not boring.

\section{Implementation of Learning in Class XI}

Based on the results of observations of the implementation of online learning in biology lessons in class XI IPA 1 and XI IPA 2, online learning activities begin 5-10 minutes before the specified biology lesson hours. The teacher opened the learning activity by saying the greeting "good morning...." and providing perception by asking about the student's news or conveying what has been learned. After that, the teacher explains the purpose of learning. Then the teacher will give material on the core activities. In the core activities, the teacher does not always provide the subject matter in the form of video, or PPT, because at some meetings, the teacher only asks questions and asks students to answer and discuss those questions during learning activities. The learning video is given in the form of videos that can be directly downloaded and videos connected to Youtube. The video or PPT given contains questions that are used as discussion activities or used as tasks. The teacher also gives students the opportunity to ask questions, and gives other students the opportunity to answer their friends' questions first, then the teacher will answer the student's unanswered questions and confirm the correct answer. The student's response is active in learning. Then, the teacher will have the student conclude the subject matter, and at some meetings the teacher also provides a summary for the student to learn. Teachers also always provide motivation to students during learning, such as commenting on students who answer questions or active students and commenting on the results of student assignments such as "thank you.... Have answered the question, there are others who want to add "thank you for collecting tasks" or "thank you who have responded and answered". In online learning activities, there are also practicum activities.

Based on the results of interviews conducted with class XI students, it is as follows.
1) How are the online learning activities that have been implemented?

"The teacher gives the material in the form of a video or a note to understand. Then we are given the question".

"The teacher uses an explanatory video from Youtube and discusses the questions in the video. How are the practicum activities that you have done during online learning activities?".

2) How are practicum activities that have been carried out during online learning activities?

"Practicum activities in biology are watching practicum videos that teachers have done, and then we make a report. This is quite helpful for us in learning online."

"Observing practicums that have been done through Youtube and making observations".

3) Describe practical applications applied to online learning activities?

"Google Classroom, this application provides benefits that are materials provided by teachers arranged neatly so that it is easier to learn".

"Google Classroom is very effective in online learning activities because it is easy to use."

4) Explain the effective learning media applied to online learning activities?

"I like the medium of learning through video and PowerPoint, and I think it is more interesting and not boring."

"Power points and videos from Youtube make it easy for me to understand the material".

Based on the interview with class XI students, online learning activities are usually done, namely, teachers will provide material in the form of videos or a note for students to understand, and then students are given questions either from video or PPT are observation practicum activities. The most practical application is google classroom because it is easy to use and easy to understand. Materials and tasks are neatly arranged to be easy to learn and can be seen at any time. An effective learning medium is a video because it makes it easy to understand the material and not get bored in learning.

\section{Implementation of Learning in Class XII}

Based on the results of observations of the implementation of online learning in biology lessons in class XII IPA, the defence activities opened with the teacher saying hello, and conveyed connecting the lessons learned at the previous meeting with those to be learned. The teacher also conveys the purpose of learning in this preliminary activity. In core activities, the teacher does not always provide the subject matter in the form of video, or PPT, because at some meetings, the teacher only asks questions and asks students to answer and discuss those questions during learning activities. The video provided 
can be directly downloaded, and the video is connected to youtube. Teachers always allow students to ask questions about materials that are not yet understood and convey that liveliness will also be assessed in learning. The response of class XII students is very active. At closing activities, teachers ask students to infer material from a given video, sometimes also giving assignments. Teachers are also always motivated by students. In class XII practicum activities are also still applied.

Based on the results of interviews with students of class XII, the following.

1) How are the online learning activities that have been implemented?

"The teacher explained video, and then we were given a task related to the material."

"Interesting because learning is not monotonous, the material is given via video, and there are not always tasks. In learning, there are also discussion activities."

2) How are the practicum activities that you have done during online learning activities?

"Practicums are conducted individually, and make practice reports."

"The practicum is done that we are asked to search for reports from the internet, then answer the teacher's questions as obtained."

3) Describe practical applications applied to online learning activities?

"Google Classroom, because there is a notification if there is material or task given and makes it easy to see the value of the task."

4) Explain the effective learning media applied to online learning activities?

"Video makes it easy for us to understand the lesson." "Effective media used during this online learning is in the form of video."

Based on the results of class XII students' interviews, online learning activities that are usually carried out are teachers giving explanations via video. Then there are discussion activities, assignments, and independent practicum activities. Students also state that the most effective application is Google Classroom because it makes it easier for students to know if there are new assignments/materials through notifications, and it is easier to know tasks that have not been done and can also see the value of assignments online. The most effective learning media are video and youtube, but some students also answer PPT more easily understood. The results of interviews with biology teachers at Xavier Lubuklinggau High School are as follows.

a) What is the biological learning procedure that you apply online?

"Open the lesson by saying hello, then explain the steps students must take, and provide material. Material is provided via video or PPT. Mothers also sometimes only give questions and ask students to answer these questions so that there are discussion activities to be seen active in learning. Some students ask WA (WhatsApp), still, no one asks. Class $X$ is inactive in learning".

b) What apps do you usually use during online learning? "Google Classroom, Youtube, Google Form, Mom used Ms. Form as well, actually the same as Google Form, when viewed from the look more interesting in Ms. form is just less interesting in numbering, in this application numbering from the beginning "from the name", if in google form there is part 1, part 2 so it looks more special".

c) What are the most effective applications in online learning?

"Google Classroom (GC), because networking is easier at $G C$, the RAM is not too large and facilitates learning activities, and in GC can include videos, PPT, assignments, and discussions.".

d) What kind of media do you use to support online learning?

"Video and PPT".

e) How do you apply the learning model during online learning?

"The learning model applied during online learning is the discovery learning model, while the inquiry and other learning models have never been used during online learning activities because they are still confused how to apply other learning models with conditions like this"

f) What strategies do you use in online learning?

"Using interesting learning videos. Before teaching, must evaluate the video to be given. Usually, the video is given with two video options, namely videos that can be directly downloaded and connected to Youtube, and pay special attention to students who are lazy to learn".

g) Is the practicum still implemented in learning?

"Still, but not all practicums can be applied. Practicum activities that are applied are related, such as biodiversity materials and species name writing. Practicums that require using laboratory tools and materials are usually done by sending practicum videos that have been done as well as practicum results and asking students to analyze those results and make reports."

Based on the interview results with the biology teacher, online learning activities that are usually carried out are teachers opening learning by saying hello, then explaining the learning goals and steps that students must take and providing subject matter to students. Material is given in the form of PPT and videos containing questions used as discussion materials or as assignments for students. The teacher asks students to ask if the material is not yet understood and allows students to ask questions. The teacher also stated that he paid particular attention to lazy 
students learning by sending private messages. Practicum activities can also still be applied in classes X, XI and XII. It is just that not all practicums can be carried out online. Applications used by teachers during online learning are Google Classroom, Youtube, WhatsApp, Google Form, Microsoft From. Learning media used by teachers are power points, videos, and biology package books. The learning model used during online learning is the discovery learning model; teachers have not applied other learning models.

\section{Evaluation}

Based on the results of interviews with biology teachers are as follows.

a. During online learning, how do mothers perform effective assessments?

"by conducting student discipline in collecting assignments, student activities in learning."

b. How do you do cognitive assessments?

"with repeats per basic competency, tasks. The curriculum is not required to be achieved all during online learning so only the important cores of the KD must be fulfilled. The replays given are usually multiple-choice, but sometimes also combined with essays and from tasks that answer questions."

c. How do you do psychomotor assessments?

"Reported practicum"

d. Does the mother have difficulty in making judgments?

"Of course there is, the problem is found the same child's answer, difficulty to contact directly outside of KBM hours and supervision".

e. Do you give assignments during online learning?

"Yes, but not every student, because later many want to be corrected, and they will also be saturated, so we have to pay attention to their condition as well."

f. What kind of task does it usually give you?

"The form usually answers questions, later photographed sent at GC, then reports of practice results, as well as notes".

Based on the results of interviews with biology teachers at Xaverius Lubuklinggau High School, attitude assessment is carried out by assessing students' activeness during biology learning and punctuality in task collection. Assessment of knowledge on learning is done by providing questions of repetition of essential competition and student assignments. The task given by the teacher is in the form of answers to questions, notes, and practicum reports. The problems that are usually made are a matter of multiplechoice and essay problems. Skills assessment is done by assessing the student practicum report. Obstacles to assessment are finding the same student answers, difficulty in conducting supervision during the assessment, and difficulty contacting some students outside of biology lesson hours. Some students must be reminded constantly to work on the problem.

Based on the results of interviews with students of grades X, XI and XII, namely "what is the form of tasks given by teachers during online learning?"

a: "The form of tasks is usually a problem, notes and makes a report."

$\mathrm{b}$ : "The form of the task is the record, the problem training and the form of the report."

c: "report, summary or answer the question."

Based on the observations in classes X, XI and XII, there are evaluation activities carried out in online learning activities. Affective assessment is carried out by assessing the student's activeness and the timeliness of the assignment collection. Assessment of knowledge in classes $\mathrm{X}, \mathrm{XI}$ and XII are done by repeating primary competition, assignments, and answers to questions given by teachers. Teachers use Google Form services in repeat implementation and have set the time in their collection so that students who are late to collect assignments will be seen. Teachers will provide student grade results and hold remedial activities for students who get grades under KKM. Teachers also comment on student assignments such as deficiencies or errors in the work of assignments or praise students who get the highest grades, but teachers only give those comments to some students in class XII. Tasks were given in the form of material records, problems, posters and practicum reports. Skills assessment is done by assessing the student practicum report.

\section{Factors affecting online learning}

Based on the quetioer results given to classes X, XI, XII IPA to obtain data on factors that affect online learning. Based on the results of the student questionnaire given to 116 students, 113 students answered. Internal factors consist of learning interests, learning motivation, preparation and talent. In the interest factor of student engagement indicators, students state that they are interested and eager to learn biology, but they are embarrassed and afraid to ask teachers, then on motivation only on indicators of a conducive environment, which hinders online learning. Some students state that they are looking for a quiet place during learning while listening to songs or sitting in the study, but there are obstacles such as doing new homework can learn, crowded home conditions, and notifications on mobile phones that interfere with learning concentration. The readiness factor of students in learning has obtained the result that the average student is ready in learning activities, from infrastructure, understanding how to use applications used in online learning, preparing biology books before learning. However, class $\mathrm{X}$ students express a lack of confidence, shame, and fear of asking teachers about the mental aspect. 
Factors of student talent, only in intellectual piercings that affect students in learning, students state that some materials are difficult to understand because the material is not explained in detail during online learning.

External factors consist of family, school and community environmental factors. Factors that affect online learning activities are family factors. Seventy-three parents do not play a role in helping them during online learning. The next factor is the school factor, the teacher has provided teaching materials and made exciting learning activities, as well as helping students overcome difficulties, but the obstacles are that some teachers provide many tasks so that students do not have time to learn. Some materials are difficult to understand because some of the materials described are not detailed, and sometimes there are no question and answer activities during learning. External factors that do not affect online learning activities are community factors. The average student states that not following activities in the community, but mass media such as the internet is very helpful in learning while friends to get along during online learning activities also do not hinder them from participating in online learning activities.

Based on the results of interviews with biology teachers are as follows.

\section{a) What factors hinder online learning?}

"The application and assessment of the character of students, especially in class $X$ because they have never met the student, while for class XI and XII, the mother already knows some students who are lazy to learn and who have difficulty understanding the material, to pay special attention to the student. You will send private messages to these students to remind them to learn and collect assignments. The obstacle is also to awaken the motivation of students, especially class $\mathrm{X}$ and class XI students. Students in class $\mathrm{X}$ are less active in learning. The next obstacle is the time to study biology is only a little, so you have to really find a way to convey the subject, supervision in assessment, and obstacles to contact students outside of lesson hours, because some students were often late to collect assignments.

\section{b) What factors support online learning?}

"Online training or seminars, then pulse assistance from schools and ministries, infrastructure facilities that have been supported, and biology printed books that have been distributed to students".

Based on the results of the interview, the teacher stated that the factors that hinder online learning are the motivation of some students who are still low, students are less active in learning, especially class $\mathrm{X}$, supervision in assessment, little biological study time, some students must get special treatment and difficulty in assessing student character.

\section{Discussion}

\section{Learning Planning}

The implementation of learning activities must begin with learning planning activities. The teacher makes learning devices such as learning implementation plans (RPP) and syllabuses in this activity. Based on the study results, the syllabus used by teachers following the Circular Letter of the Minister of Education and Culture Regulation No. 14 of 2019 is a character assessment in students. It is also under interviews with biology teachers that there is a character assessment. Character assessment is essential in learning and is also a competency that is expected to be achieved during learning activities, including at Xavier Lubuklinggau High School. This character education aims to build the character of students who have faith, independence, and tenacity able to face problems well to achieve success (Supriyadi, 2015). A biology teacher at Xaverius Lubuklinggau High School stated that online learning could not assess students' character.

Another learning device prepared by the teacher is RPP. RPP made by biology teachers is RPP one sheet. The RPP component compiled by teachers for classes X, XI and XII contains core components, namely learning objectives, learning and assessment activities, and complementary components consisting of school identity, subjects, time allocation, class or semester and essential competencies. In general, biology teachers at Xaverius Lubuklinggau High School have compiled a good RPP, because the RPP has fulfilled most of the components contained in the Circular Letter from Permendikbud No. 14 of 2019 there is only one component that has not been fulfilled, namely in the complementary components, teachers do not write the subject matter on RPP.

\section{Implementation of Learning}

Based on the research results, the implementation of biology learning classes X, XI, and XII IPA follows the RPP that has been prepared. Teachers have tried to manage and create excellent and exciting learning activities, using various applications and learning media to deliver subject matter, and there are independent discussions and practicum activities. Teachers also provide rules that students must follow during online learning activities $\mathrm{X}, \mathrm{XI}$ and XII.

The application used during online learning activities in biology lessons uses the Google Classroom, Youtube, Google Form, and WhatsApp applications. The most effective application during online learning in this school is Google Classroom. This is also revealed from the results of research from Hikmatiar, Sulisworo, \& Wahyuni (2020) and Maharani \& Kartini (2019) shows that the Google Classroom application has exclusive features that support learning and from the results of research that this 
application can increase students' motivation, interest and learning outcomes.

The learning media used by biology teachers in this school is the video learning media and PPT. Based on the study results, students like the medium of learning in the form of video in the delivery of material because it makes it easier for students to understand the material provided and not boring. This is in accordance with the results of research Azis, Taiyeb, \& Muis, (2018) states that the use of video makes students more motivated and enthusiastic in learning and improves learning outcomes. It is also revealed in Gazali \& Nahdatain (2019) research which states that well-packaged learning videos using easy-tounderstand explanations can improve students' learning spirit and make students not bored in learning.

The learning model used by teachers during online learning activities is the discovery learning model. The teacher stated that he had not tried to use other learning models during online learning activities. Learning activities consist of preliminary activities, core activities and closing activities. The preliminary activities conducted in class X, XI and XII IPA at Xavier High School began with the teacher always opening learning activities by saying "good morning". The teacher conveys perceptions such as asking about students and saying "we meet again in biology class, whether you have drank water or breakfast". Teachers always convey the purpose of learning to students, and sometimes teachers also connect the previous subject matter with the material to be taught even though not every learning.

This preliminary activity is important in learning activities because it can focus students before learning activities begin. Perception activities aim to construct students' thinking so that they can understand the lesson in a structured manner (Sudarisman, 2015). This was also expressed by Suryadi (2020) and Pakungwati (2018), who stated that perception is an important stage in learning because it can strengthen students' concepts. Moreover, during online learning, which is a new thing for students, it is necessary to focus students, encourage students to learn, and help students understand the lessons in a structured manner. Based on the results of Octaviani's research, et all (2020) that the perception that can be used during online is able to utilize the environment around the student's home and good perception can make students more active and critical in learning.

The core activities in class $\mathrm{X}$ are teachers providing subject matter in videos and PPT. The video and PPT provided contain questions and ask students to write down answers in their notebooks and submit those answers. Teachers always allow asking and responding to their friends' questions, but students' response in class $\mathrm{X}$ is less active. This is following the results of an interview with the teacher who stated that class $\mathrm{X}$ is less active, although motivation is always given to students in every learning. While based on the results of interviews with students, he stated that he lacked the confidence to be active in learning because he did not know the teacher who taught and felt afraid. This is also revealed from the results of research that states that online learning activities that are only done by providing materials and assignments without discussion cause low student interaction, and lack of communication between students and teachers will also make the online learning process boring (Kurniasari, Pribowo, \& Puta, 2020).

The core activity in class XI is that the teacher provides material in video or PPT. Videos are usually provided with two video options: videos that can be directly downloaded and videos connected to Youtube, so students can choose videos that make it easier for them to learn. The video provided also contains questions that must be answered by students or used as discussion materials. The teacher was also asked to summarize the material from the video given. The teacher also said that the activeness and assessment in punctuality in the collection of tasks would also be assessed.

The response of class XI students during learning is to appear active only when there are discussion activities. In this activity, some students ask and answer questions of their friends, then the teacher will confirm the student's answer and answer unanswered questions, but when the teacher only gives material without any questions, students look less active. This is following the results of Mustakim's research (2020: 8) that with the discussion method, teachers and students can increase direct interaction in learning so as to facilitate students during the online learning process.

The core activity in class XII is the provision of material. The material is given in the form of a video with the same two video options, namely videos that can be directly downloaded and videos connected to Youtube. At several meetings, the material is given in the form of 3 different learning videos, such as aerobic respiration material. The teacher gives three videos at once in one meeting, namely glycolysis video, Krebs cycle and electron transport. In the next activity, the teacher asks students to record material from the results of watching the learning video and answer the questions contained in the video. Indirectly, the teacher asks students to conclude the lesson that has been given. Teachers always provide opportunities to ask and respond to questions and convey that there is an assessment of activeness during learning. Discussion activities are also applied during online learning activities in class XII. The response of class XII students seemed very active. This is in line with Pratama \& Mulyati (2020) states that online learning activities that can be done are teachers preparing teaching materials that will be given to students, choosing learning media that suit the student's circumstances, 
teachers sending the teaching materials to students either videos, problem exercises, modules or others, allowing students to ask and explain the answers to the question, and conduct evaluations and feedback.

Closing activities carried out in classes X, XI and XII IPA are the conclusion of learning. These conclusions are sometimes given by teachers or used as assignments for students. Assignments are also given during online learning activities in classes X, XI and XII IPA at the end of learning. Assignments are given not in every learning activity. This is following the results of the interview that the teacher stated that he does not always give students assignments because of thinking about the health of students and the saturation of students in learning. This is also supported by the results of Prawanti \& Sumarni (2020) research stating that tasks given during online learning that are too much can make students feel bored to learn, and the collection of tasks that are only given in the form of photo or video makes teachers difficult and exhausted to correct the task. The biology task given by the teacher at Xavier High School is a summary of watching videos, answers to questions, or reports. This is also revealed from the results of Ambarsari research (2021), which states that during online learning tasks can indeed be given practically to learners, tasks given online can also vary. The obstacle to the closing activities is that the teacher does not convey the lessons to be learned at the next meeting that requires students to study at home. The teacher only ever reminds students to learn at a time when students will carry out repeat activities.

Motivation is also always conveyed in every learning activity in class X, XI and XII IPA, this can be seen from the statement "happy learning", "keep the spirit of learning", commenting on students' answers with "answers.... True, there are others who want to add", "thank you for responding and dare to ask" or give the symbol "ß". Providing motivation is very important during online learning. Students who have high learning motivation will always be passionate in learning so that it will have a positive impact on the student's own learning achievement (Febriandar, 2018). The results of Ajar, Prasetiawan support this, \& Surdaryanti (2020) research states that providing student motivation during online learning can improve student learning outcomes. The results of research from Syachtiyani \& Trisnawati (2021) indicated that student learning outcomes improved along with students' learning motivation which was also high.

Based on the results of research, biological practicum activities can still be applied during online learning activities. The practicum given is an independent practicum that individual students must do. Practicums that have been applied are related to nature, such as biodiversity, making a cladogram, while practicums that require laboratory materials and tools, teachers only send practicum videos that have been done by teachers or others and ask students to observe the results of the practicum and make observation reports. This is following the results of Sholika's research, et ll. (2020), which states that biological practicums are still carried out during online learning. However, practicums are practicums that use simple tools and materials only, and some practicums cannot be done during online learning because of the tools and materials that students have to do independent practicums. It is also supported by Saraswati \& Martayasa (2020), who stated that some practicums are challenging to implement during online learning. Empowerment of resources or tools and practicum materials that every student at home will support practicum activities independently (Sumardi et al. 1, 2020).

\section{Evaluation}

The online assessment process provides a change both in learning and in assessment. Assessments that are usually done face-to-face must be changed by online that utilizes technology. The assessment designed by biology teachers at Xaverius Lubuklinggau High School during online learning has been thoroughly compiled from assessing attitudes, knowledge and skills. The assessment of attitudes carried out by teachers is to assess students' activeness during learning and assess student discipline from timeliness in the collection of tasks. The teacher's knowledge assessment is a daily repeat in multiple-choice and essay, midterm repeat (UTS), end of semester repeat (UAS), and assignment. The teacher's skill assessment is to assess the practicum report made by the student. The implementation of the assessment also can not be separated from some obstacles such as supervision in the assessment, difficulties in the assessment of character and attitude of students. It is also supported in the results of research Hafiz, Deniartia, \& Anisa (2020), which states that during online learning, found the same student answers, unable to observe students during assessment and difficulties in affective assessments they cannot observe students directly during learning.

\section{Factors Affecting Online Learning}

The implementation of online learning can be done because there are supporting factors. This was revealed by biology teachers at Xaverius Lubuklinggau High School that the factors that support the implementation of online learning are infrastructure facilities that have been supported, quota assistance from schools and ministries, students have received biology package books, discussions between teachers about online learning, and the existence of online training and seminars.

Factors that hinder online learning are the motivation of some students who are still low, students are less active in learning, especially class $\mathrm{X}$, supervision in assessment, little 
biology study time, some students must get special treatment, and difficulty in assessing the character of students. Based on the results of Sadikin \& Hamidah (2020) research, online learning does have special challenges. The learning process is carried out separately between teachers and students so that teachers cannot observe students directly in learning. This leads to that there is no guarantee that students are earnest in listening to reviews from teachers. According to Yunitasari \& Hanifah (2020), the constraints on the online learning process are not being able to monitor students directly, cannot assess the character of students, some materials are delivered less effectively, and lack learning time. Problems arise also such as not all teachers and students master technology, and some teachers give assignments every meeting (Aji, 2020).

Based on the results of the student questionnaire given to 116 students, 113 students answered. Internal factors consist of learning interests, learning motivation, preparation and talent. The interest factor consists of 4 indicators: interest, feelings of pleasure, attention, and student engagement. Factors that influence online learning are on indicators of student engagement, students state that they are interested and eager to learn biology but they are embarrassed and afraid to ask teachers. This is in accordance with the results of research Meidawati (2019) and Sadikin \& Hamidah (2020) that online learning has a positive impact in students' learning interests, online learning also keeps students in the spirit of learning, increasing students' interest in learning.

Motivational factors consist of 6 indicators: the desire and desire to learn, the appreciation in learning, the encouragement of learning needs, expectations of future ideals, interesting activities, and a conducive environment. Factors that hinder online learning are only in conducive environmental indicators. Some students state that they are looking for a quiet place during learning, while listening to songs or sitting in study but there are obstacles such as doing new homework can learn, crowded home conditions and there are notifications on mobile phones that interfere with learning concentration. This is in accordance with the research results from Fitriyani et al. (2020) stated that online learning conducted during the Covid-19 pandemic did not hinder students' spirit in learning, although there are still many shortcomings and obstacles faced. It is also supported by Mustofa (2020), which states that online learning positively impacts student motivation. Students are still eager to learn, provide students with the need for the information needed and have flexible time to repeat and review the subject matter. It is also supported by Cahyani, Listiana, \& Puteri (2020) obstacles in increasing student motivation, namely the atmosphere when studying at home.
The readiness factor of students in learning has obtained the result that the average student is ready in learning activities, from infrastructure, understanding how to use applications used in learning, preparing biology textbooks before learning. However, many X-class students lack confidence, shame, and fear of asking teachers on the mental aspect. Purwanto et al. (2020) revealed that facilities are essential to launching learning activities such as laptops, computers, or mobile phones that will facilitate online learning activities can run well.

The talent factor consists of 3 indicators, namely intellectual, motivation and creativity of students. Factors that affect online learning only in intellectual piercing, students state that some materials are difficult to understand because the material is not explained in detail during online learning. It is also supported by the results of research from Sadikin \& Hamidah (2020) that the subject matter provided online is challenging to understand. The material and tasks are not enough because it needs to be explained directly by the teacher.

External factors consist of family, school and community environmental factors. Factors that affect online learning activities are the family factor. Seventy-three parents do not play a role in helping during online learning. This is following the research that According to Putria, Maula, \& Uswatun (2020), supportive facilities support online learning constraints, still constrained in students who are lazy to learn, and still, many parents who are busy working they cannot guide students in learning.

The next factor is the school factor, many students answer that the teacher has provided teaching materials and made exciting learning activities, as well as helping students overcome difficulties, but the obstacle is that some teachers provide many tasks so that students do not have time to learn. Some materials are difficult to understand because some of the materials described are not detailed, and sometimes there are no question and answer activities during learning.

External factors that do not affect online learning activities are community factors. The average student states that they do not follow activities in the community. However, mass media such as the internet is beneficial for them in learning while for friends to get along during online learning activities also do not hinder them in participating in online learning activities.

\section{Conclusion}

It can be concluded that the factors that affect online biology learning are interest and motivation factors; students are interested and eager to learn even online; the obstacle is only X-class students who are less active in learning. Because they feel less confident and afraid to ask teachers, some students find it challenging to find a conducive environment because they have to while doing 
homework and crowded home conditions. The lack of the role of parents in guiding students to learn, supervision of assessment, time limitations in the explanation of materials, difficulty in assessing the character of students also includes obstacles in online learning. Factors that support online learning are infrastructure facilities, pulse/quota assistance, stable networks, students who have received biology package books, discussions about online learning, and online training and seminars.

\section{Declaration statement}

The authors reported no potential conflict of interest.

\section{References}

Agoestyowati, R. 2020. Dampak positif dan negatif tentang pembelajaran online saat pandemi Covid-19 melanda (April, Mei, Juni 2020) Di Institut Stiami Jakarta: Aksara Publik.

Ajar, A. K., Prasetiawan, H., \& Sudaryani, S. 2020. Upaya Meningkatkan Motivasi Belajar Daring dengan Bimbingan Kelompok Pada Siswa Kelas XI TSM SMK Murni Surakarta Tahun Ajaran 2020/2021. Prosiding Pendidikan Profesional Guru Universitas Ahmad Dahlan

Aji, R. H. 2020. Dampak Covid-19 pada pendidikan di Indonesia: sekolah, keterampilan, dan proses pembelajaran. SALAM: Jurnal Sosial Dan Budaya Syari, 7(5). https://doi.org/10.15408/sjsbs.v7i5.15314

Ambarsari, R. Y. 2021. Evaluasi Pembelajaran Daring Selama Pandemi Covid-19 di Kecamatan Bulukerto Wonogiri. Jurnal Ilmiah Mitra Ganesha Vol 8 (1)

Artikawati, R. 2016. Pengaruh Mengadakan Variasi Terhadap Prestasi Belajar Siswa Kelas IV SD. Jurnal Pendidikan Guru Sekolah Dasar Vol 5 (11)

Azis, R., Taiyeb, A. M., \& Muis, A. 2010. Pengaruh penggunaan video pembelajaran terhadap motivasi dan hasil belajar siswa pada materi sistem peredaran darah. Prosiding Seminar Nasional Biologi Dan Pembelajarannya, 461-466.

Cahyani A. Listiana I, D.\& larasati S. P. 2020. Motivasi belajar siswas pada pembelajaran daring di masa pandemi Covid-19. Jurnal Pendidikan Islam Vol 3 (1)

Dhull, I. \& Sanksi. 2017. Online learning. Internasional Education \& Research Journal (IERJ), 3 (8)

Fitriyani, Y., Fauzi, I., \& Sari, M. Z. 2020. Motivasi belajar mahasiswa pada pembelajaran daring selama pandemik Covid-19. Profesi Pendidikan Dasar, 7(1), 121-132. https://doi.org/10.23917/ppd.v7i1.10973

Gazali, Z., \& Nahdatain, H. 2019. Pengembangan media pembelajaran berbasis video pada materi biologi sel untuk siswa SMA/MA Kelas XI IPA. JUPE: Jurnal Pendidikan Mandala, 4(5), 236-238. https://doi.org/10.36312/jupe.v4i5.867
Hafiz, M., Desniarti, \& Anisa, Y. 2020. Pembelajaran Daring Yang Dihadapi Guru Sekolah Menenga Atas. Jurnal Ilmu Pendidikan (JIP) Vol 1(2)

Hikmatiar, H., Sulisworo, D., \& Wahyuni, M. E. 2020. Pemanfaatan learning manegement system berbasis google classroom dalam pembelajaran. Jurnal Pendidikan Fisika, 8(1), 78-86. https://doi.org/10.26618/jpf.v8i1.3019

Kurniasari, A. Pribowo F. S. P., \& Putra D. A. 2020. Analisis Efektifitas Pelaksanaan Belajar dari Rumah (BDR) Selama Pandemi Covid-19. Jurnal Kajian Pendidikan dan Hasil Penelitian Vol 6 (3)

Maharani, N., \& Kartini, K. S. 2019. Penggunaan google classroom sebagai pengembangan kelas virtual dalam keterampilan pemecahan masalah topik kinematika pada mahasiswa jurusan sistem komputer. PENDIPA Journal of Science Education, 3(3), 167-173. https://doi.org/10.33369/pendipa.3.3.167-173

Meidawati, S. A. N. B. R. 2019. Persepsi siswa dalam studi pengaruh daring learning terhadap minat belajar IPA. SCAFFOLDING: Jurnal Pendidikan Islam dan Multikulturalisme, 1(2), 30-38. https://doi.org/10.37680/scaffolding.v1i2.117

Mustofa, M. I., Chodzirin, M., Sayekti, L., Negeri, U. I., \& Semarang, W. 2019. Formulasi model perkuliahan daring sebagai upaya menekan disparitas kualitas perguruan tinggi (Studi terhadap Website pditt.belajar.kemdikbud.go.id). Walisongo Journal of Information Technology, 1(2), 151-160.

Mustofa, W. A. A. S. M. H. M. R. 2020. Analisis motivasi belajar mahasiswa dengan sistem pembelajaran daring selama masa pandemi Covid-19. Jurnal Equation IAIN Bengkulu, 3(2), 157-171.

Mutaqinah, R., \& Hidayatullah, T. 2020. Implementasi pembelajaran daring (Program BDR) selama pandemi Covid-19 di Provinsi Jawa Barat. Jurnal Petik, 6(2), 86-95.

Octaviani, F. R. et. all. 2020. Apersepsi Berbasis Lingkungan Sekitar Sebagai Pemusatan Fokus Pembelajaran Biologi Selama Pembelajaran Daring. Buletin Pengembangan Perangkat Pembelajaran Vol 2 (2)

Pakungwati, I. F et. all. 2018. Dampak Penguatan Apersepsi dan Pemberian Tugas terhadap Penguasaan Konsep Siswa. Unnes Physics Education Journal Vol 7 (3)

Pratama, R. E. \& Mulyati, S. 2020. Pembelajaran Daring dan Luring pada Masa Pandemi Covid-19. Gagasan Pendidikan Indonesia Vol 1 (2)

Prawanti, L.T. \& Sumarni, W. 2020. Kendala Pembelajaran Daring Selama Pandemi ovid-19. Seminar Nsional Pscasarjana ISSN: 26866404

Purwanto, A., Pramono, R., Asbari, M., Santoso, P. B., Wijayanti, L. M., Choi, C. H., \& Putri, R. S. 2020. Studi 
Eksploratif dampak pandemi covid-19 terhadap proses pembelajaran online di sekolah dasar. EduPsyCouns: Journal of Education, Psychology and Counseling.

Putria, H., Maula, L. H., \& Uswatun, D. A. 2020. Analisis proses pembelajaran dalam jaringan (Daring) masa pandemi Covid-19 pada guru sekolah dasar. Jurnal Basicedu, 4(4), 861-872. https://doi.org/10.31004/basicedu.v4i4.460

Regianti, H. A. 2020. Kendala Pembelajaran Daring Guru Sekolah Dasar di Kabupaten Banjarnegara. Jurnal Elemantary School Vol 7 (2) e-IISN25024264

Sadikin, A., \& Hamidah, A. 2020. Pembelajaran daring di tengah wabah Covid-19. Biodik, 6(2), 109-119. https://doi.org/10.22437/bio.v6i2.9759

Saraswati,N. L. \& Mertayasa, I. N. 2020. Pembelajaran Praktikum Kimia Pada Masa Pandemi Covid-1; Qulitative Content Analysis Kecenderungan Pemanfaatan Teknologi Daring. Wahana Matematika dan Sains; Jurnal Matematika, Sains, dan Pembelajarannya, Vol 14 (2)

Sholikas, et.all. 2020. Studi Eksplorasi Kegiatan Praktikum Sains Saat Pandemi Covid-19.Indonesian Jurnal of science learning Vol 1 (2)

Sudarisman, S. 2015. Memahami Hakikat dan Karakteristik Pembelajaran Biologi dalam Upaya Menjawab Tantangan Abad 21 Serta Optimalisasi Implementasi Kurikulum 2013. Jurnal Florea. 2 (1) http://doi.org/10.25273/florea.v2il.403

Sukmawati. 2016. Analisis faktor-faktor penghambat dalam pembelajaran daring. Pedagogy, 1, 142-150.

Sumardi, et. all. 2020. Belajar Enzim dari Ruma; Penguatan Pembelajaran Berbasis Praktikum Pada Guru di Sekolah Menenga Atas Kabupaten Tulungbawang

Supriyadi, E. 2015. Pendidikan dan penilaian karakter di Sekolah Menengah Kejuruan. Jurnal Cakrawala Pendidikan, (2), 110-123. https://doi.org/10.21831/cp.v0i2.7590

Syachtiyani, W. R. \& Trisnawati, N. 2021. Analisis Motivasi Belajar dan Hasil Belajar Siswa di Masa Pandemi Covid-19. Prima Magistra; Jurnal Ilmiah Kependidikan Vol 2(1)

Syarifudin, A. S. 2020. Impelementasi pembelajaran daring untuk meningkatkan mutu pendidikan sebagai ampak diterapkannya social distancing. Jurnal Pendidikan Bahasa Dan Sastra Indonesia Metalingua, 5(1), 31-34. https://doi.org/10.21107/metalingua.v5i1.7072

Yunitasari, R., \& Hanifah, U. 2020. Pengaruh pembelajaran daring terhadap minat belajar siswa pada masa Covid 19. Edukatif: Jurnal Ilmu Pendidikan, 2(3), 236-240. 